\title{
Knowledge creation processes in small and medium enterprises: A Polish perspective
}

\author{
Celina Sołek-Borowska, Warsaw School of Economics, csolek@sgh.waw.pl
}

\begin{abstract}
The focus of this paper is to analyze small and medium enterprises through a knowledge management perspective. More specifically, the aim of the research is to further the understanding through what processes small and medium enterprises operating in the Polish market to create knowledge. Knowledge creation processes are vital to knowledge management initiatives of companies that operate in a changing environment and depend on innovation to gain the competitive advantage. Such processes significantly differ in small and large firms. Therefore, in the following study, a thorough investigation of knowledge creation processes is presented. This research attempts to fulfill the knowledge creation processes gap between small and medium enterprises in the Polish context where traditionally large firms are mainly investigated.
\end{abstract}

Keywords: knowledge creation, small and medium enterprises, implicit and explicit knowledge, knowledge management

\section{Introduction}

Knowledge has become an essential source of value generation and sustainability of organizations' competitive advantage (Teece, 2005; Nonaka and Takeuchi, 1995). Firms that develop and leverage knowledge resources achieve greater success than firms who are more dependent on tangible resources (Autio et al., 2000). Knowledge management is increasingly becoming an integral business function for many companies, as they realize that organizational competitiveness hinges on the effective management and creation of knowledge (Varun Grover and Davenport, 2001; Randeree, 2006).

Accordingly, firms must find ways to adequately manage knowledge. This presents a challenge for smaller firms as they usually lack the suitable resources in order to make full usage of their knowledge stock. Under such conditions, this knowledge stock is particularly at risk in situations of staff turnover and/or long-term absentees creating difficulties for immediate staff replacement (Desouza and Awazu, 2006).

Although knowledge creation is viewed by scholars as fundamental for securing a sustainable competitive advantage (Nonaka, 1994; Nonaka and Takeuchi, 1995; Prahalad and Hamel, 1990; Teece, 2005) and has become a widespread concern for firms operating in turbulent and hypercompetitive environments, few studies have systematically investigated the specific knowledge creation processes put in place by small and medium enterprises.

Understanding knowledge creation processes are critical for small and medium enterprises in their effort to make optimum use of both explicit and tacit knowledge flowing within the organization. 
Therefore, in this paper, the focus is on analyzing small and medium enterprises through a knowledge management perspective. More specifically, the aim of the research is to further the understanding of how and through what processes small and medium enterprises operating in the Polish market create knowledge ${ }^{1}$. The reasons for selecting a Polish sample of small and medium enterprises are three-fold. First, small and medium enterprises in Poland generate 50.01\% of GDP.

Second, Poland constitutes the 6th position amongst EU countries to have a large number of SME companies - about $69.2 \%$. Third, most research is devoted to large companies mainly with a foreign capital where knowledge management systems are implemented according to the headquarters plans with no room for improvement (Polish Agency of Entrepreneurship Development, 2016).

Previous research on KM in SMEs has shown many differences compared to larger firms. SMEs tend to place more emphasis on management of tacit knowledge than larger firms, and communication channels in SMEs are more likely to be between firms, rather than internal to the organization. The SME sector appears to be less advanced in terms of knowledge construction, having a more mechanistic approach to this concept and relying less on social interaction (Durst and Edvisson, 2012). Serenko (2013, p. 792) concurs that "KM in small and medium enterprises is "... one of a list of several important topics that have not received sufficient attention in previous KM research. "

Knowledge creation processes are an important aspect of knowledge management initiatives of companies that operate in a changing environment that depend on innovation to compete. Such processes significantly differ in small and large firms. Therefore, in the present study, knowledge creation processes are presented in small and medium enterprises that are regarded as an efficient means for introducing knowledge management systems.

The next section provides a brief overview of the knowledge creation processes. It is continued by explaining the research methodology adopted in this study. An in-depth analysis of findings follows. The paper is concluded with a detailed discussion of the results in the light of extant literature and presentation of avenues for future research.

\section{Literature review - Knowledge creation}

The key challenges for SMEs are the identification, capture, storing, mapping, dissemination, and the creation of knowledge from different perspectives and for different purposes. It is found that managing knowledge assets in SME is not an easy task. It is an integrated and complex social process, which has culture, people, finance, technology and organizational structures at its core (Egbu et al., 2005). The need for knowledge renewal is particularly acute in SMEs (Martin et al., 2002).

The major advantages of SMEs lie on two fronts, namely, the simplicity of their internal structure and the porosity of their organizational boundary. As a result, they are poised to forge strong social connections internally and maintain close contact with the market (Wee and Chua, 2013).

\footnotetext{
${ }^{1}$ The presented results are part of the Statutory Research executed by the Management Institute KZiF/S/35/16
} 
Based on the systematic review of a literature review by Intenzari et al. (2017), three knowledge processes were identified as the main processes involved in knowledge-related organizational culture: knowledge creation, knowledge sharing, and knowledge implementation. The processes of knowledge creation, knowledge generation, knowledge construction, and acquisition were categorized under the knowledge creation process.

Similarly, knowledge sharing, knowledge distribution, knowledge diffusion, knowledge exchange and knowledge transfer were given the title "knowledge sharing". Knowledge use, knowledge reuse, knowledge application, knowledge utilization and knowledge exploitation refer to knowledge implementation.

Knowledge creation is influenced through the ability of the organization to provide social network opportunities for its employees to support stronger connections (Smith et al., 2005). Enhancing the commitment of its employees, organizations can provide opportunities for stronger knowledge creation capabilities and alignment with strategic goals.

Knowledge creation is the ability to develop new ideas or solutions (Andreeva and Kianto, 2011). The idea may, for example, be a solution to a problem or a set of novel and appropriate mental representations regarding products, processes or practices. Schulz (2001) identified three types of knowledge creation processes:

1. encoding existing knowledge in forms suitable for transmission;

2. combining existing knowledge - current information is captured and used in a historical context; and

3. production of new knowledge, which provides new insights into the organization.

Creating knowledge is the result of the individual mind's interactions and activities. In contrast, humans are affected by the culture they are in. These two dimensions (mind interaction to create knowledge and the culture) from a concept called knowledge-creation culture (Intezari et al., 2017)

SMEs face unique KM challenges which are distinct from those of their larger business counterparts. Reviewing the literature related to small businesses suggests that scholars tend to apply approaches originally developed for larger firms rather than SMEs. This procedure involves the risk that smaller firms may lose their distinct characteristics and thus their capability to act (Durst and Edvisson, 2012). Moreover, one may misunderstand the peculiarities of knowledge creation in SME's if one merely assumes that they are the same.

The creation of new organizational knowledge is increasingly becoming a managerial priority. The creation of new knowledge may come from within or outside an organization. The process of knowledge creation within an organization may be through learning, research and development, experience accumulation, and learning by doing. The source of external knowledge can be absorbed and generalized via interactions with suppliers, customers, and competitors. Chang and Lee (2008) indicated that the capability to obtain knowledge can positively and significantly affect knowledge administrative and technical innovation. The research also shows that external environment and organizational culture have significant interaction effects with knowledge accumulation capability on organizational innovation. 
Nonaka and Takeuchi (1997) suggested that the creation of knowledge is gained via the interaction of implicit knowledge and explicit knowledge. The process of knowledge convers ion is required to generate new knowledge. The conversion process includes four elements: socialization, externalization, combination, and internalization. (See Table 1)

Table 1: Knowledge creation model

\begin{tabular}{|l|l|l|}
\hline From & Implicit knowledge & Explicit knowledge \\
\hline Implicit knowledge & $\begin{array}{l}\text { Collectivity: process of } \\
\text { creating implicit knowledge } \\
\text { via experience sharing } \\
\text { (common knowledge) }\end{array}$ & $\begin{array}{l}\text { Internalization: knowledge } \\
\text { passed down with words and } \\
\text { stories or made into manuals } \\
\text { and documents (operational } \\
\text { knowledge) }\end{array}$ \\
\hline Explicit knowledge & $\begin{array}{l}\text { Externalization: implicit } \\
\text { knowledge expressed with } \\
\text { metaphors, analogies, } \\
\text { concepts, or assumptions } \\
\text { through models (conceptual } \\
\text { knowledge) }\end{array}$ & $\begin{array}{l}\text { Combination: the process of } \\
\text { forming a knowledge system } \\
\text { by making concepts } \\
\text { systematic (systematic } \\
\text { knowledge) }\end{array}$ \\
\hline
\end{tabular}

Source: Nonaka and Takeuchi (1997)

The definitions of these elements as described by Shih, Chang, \& Lin (2010) are as follows:

"Socialization refers to the process for implicit knowledge to become explicit. It is mainly through passing down and sharing personal experiences, and thus, there is no need to go through written words... Externalization is the process for implicit knowledge to become explicit knowledge. The sharing of knowledge is mainly through metaphors and conceptual assumptions... Combination is the process for implicit knowledge to become explicit knowledge, mainly through storage, combination, and classification to make the explicit knowledge systematic... Internalization is the process for explicit knowledge to become implicit knowledge, mainly via inspections and applications. The process socializes, externalizes, and combines the explicit languages, texts, pictures, or information, and then internalizes it into personal knowledge." (Shih, Chang, \& Lin, 2010, pp. 78-79).

The SECI processes are considered as models of knowledge creation (discovery and capture) (Becerra-Fernandez et al., 2004) and knowledge sharing (Becerra-Fernandez et al., 2004; Jennex and Zynger, 2007). In the research conducted by Lee and Kelkar (2013), the authors concluded that ICTs were prevalent in the various phases of the SECI model, and they were used for a variety of purposes including maintaining relationships, sharing experiences, and self-development, apart from the more traditional uses such as storing and retrieving data.

SECI model can be used as indicators of KM process. The intention to get involved in this process is, therefore, reflects the degree of employee readiness in an organization to accept and implement 
the process. In this regards, KM can be conceptualized through KM processes, which is highly observable and measurable in nature. KM readiness, on the other hand, reflects the degree to which the employees are ready to adopt these processes. (Nor Shahriza et al., 2012)

SME knowledge research is focused in three main areas. First, on the influence and abilities of the entrepreneur to extract, use, and develop knowledge resources. Second, on firm-wide systems and the social capital that facilitates knowledge exploration and exploitation. Third, on the provision of knowledge and learning experiences through government policy. From a practical perspective, the review concludes that policies encouraging entrepreneurship and economic regeneration need to be more flexible and sensitive to the often-complex contexts within which knowledge is used by SMEs (Thorpe et al., 2005). Although the literature review highlights the importance of knowledge creation and related issues but finds a huge lack of studies on knowledge creation in SMEs in Polish context.

\section{Methodology}

The results discussed in this paper are from a broader research that was carried out by the Institute of Management School of Economics in Warsaw, Poland in 2016 on 153 subjects from small and medium-sized companies. The main aim of the research was to identify what type of knowledge management systems exist in small and medium-sized enterprises. However, the results presented in this paper focus on determining what knowledge creation processes are encouraged in the SME's using the same data.

Prior to the main study, a pilot study was undertaken which helped with refining data collection plans with respect to both the contents of the data and the procedure to be followed. Data shown in Table 2 indicate that a balanced sample has been chosen for the research when it comes to the number of employed persons, which was the result of a deliberate selection of respondents. The research sample was dominated by production companies, which accounted for $50 \%$ of the surveyed entities. The predominant type of legal form of business was a limited liability company, which accounted for up to $80 \%$ of the respondents. In turn, the companies with a majority Polish capital clearly dominated $88 \%$ of the analyzed entities. As for the scope of operation, the companies accounted for an international scale were $50 \%$ of respondents while $41 \%$ accounted for regional. 
Table 2: Features of investigated companies

\begin{tabular}{|l|c|c|}
\hline Enterprise & N & $\%$ \\
\hline Type of activity & & \\
\hline Production & 75 & 49 \\
\hline Trade & 41 & 27 \\
\hline Services & 37 & 24 \\
\hline Form of ownership & 122 & 80 \\
\hline Ltd. & 21 & 14 \\
\hline Joint stock company & 10 & 6 \\
\hline Sole proprietor & & \\
\hline Type of capital & 135 & 88 \\
\hline Majority of Polish capital & 18 & 12 \\
\hline Majority of foreign capital & & 50 \\
\hline Scope of activity & 77 & 41 \\
\hline International & 63 & 9 \\
\hline National & 13 & \\
\hline Regional/ local & & 50 \\
\hline Number of employees & 77 & 50 \\
\hline 10-49 persons & 76 & \\
\hline 50-249 persons & & \\
\hline
\end{tabular}

Source: Statutory research of Management Institute 2016, (N=153)

\section{Research findings and analysis}

Many smaller firms face resource constraints (Jarillo, 1989), and existing resources must consequently be used with care, as erroneous decisions will have more serious complications than would be the case in large businesses (Amelingmeyer and Amelingmeyer, 2005). For example, small firms have a flat structure and an organic, free-floating management style that encourages entrepreneurship and innovation. They tend to be informal, non-bureaucratic and there are often few rules. Control tends to be based on the owner's personal supervision and formal policies tend to be absent in SMEs (Daft, 2007).

For each entity operating in a highly competitive environment, it is necessary to create new knowledge, only questioning the existing concepts may lead to breakthroughs and increase the level of competitiveness and innovation of the company. Respondents who participated in the study were asked to select those actions that are taken in their companies to create new knowledge. The results are presented in Figure 1. 


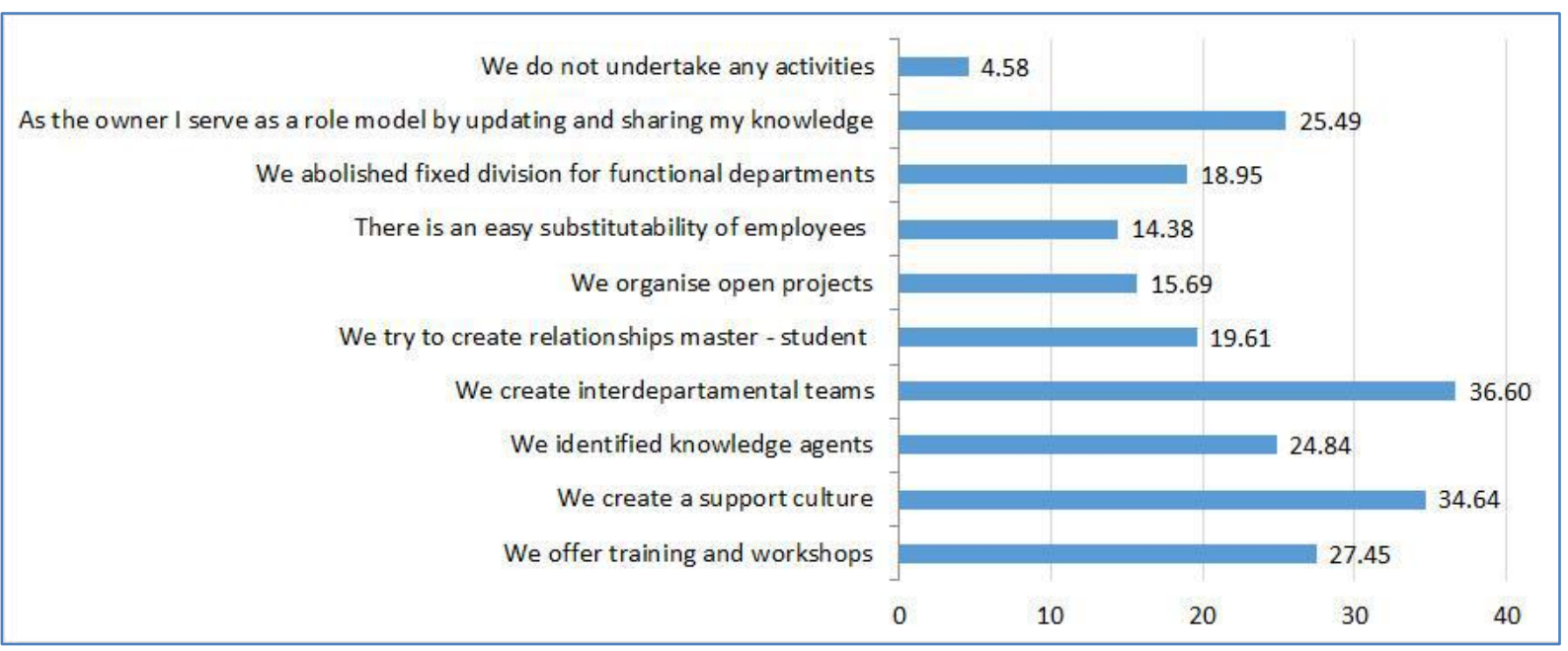

Figure 1: Activities undertaken to create new knowledge

Source: Author's own development based on statutory research of the Management Institute $(\mathrm{N}=153)$

The concept of teamwork is the most popular form of new knowledge creation, as confirmed by $37 \%$ of companies surveyed. The introduction of new ideas in the company is only possible when there is consent to commit mistakes and creating a culture of support is popularized by $35 \%$ of respondents. Personal relationships are important in SMEs, and if they are positive it is easier to achieve the desired culture (Wilhelm and Durst, 2012). Every fourth respondent identified key people in the company that are the carriers of knowledge, i.e., knowledge agents. Updating and willingness to share his or her knowledge with the employees were indicated by $25 \%$ of companies surveyed. Still, it can be argued that the transfer and sharing of knowledge are facilitated by the existence of a trusting relationship between the persons concerned (Hislop, 2009). It means that only every four boss is willing to share his knowledge and serve as a role model. Moreover, it frequently results in most knowledge being kept in the minds of the owner and some key employees. Because of a lack of size and hierarchies, employer and employees are in close contact, which can facilitate the knowledge flows among them (Desouza and Awazu, 2006).

In SMEs, personal relationships have traditionally been major contributors to organizational success. Utilizing these already existing bonds, coupled with a clear understanding of what the company wants to accomplish strategically, can become a sustainable competitive advantage that can lead to growth and increased profitability. This can result in customer satisfaction and retention.

One of the main characteristics of SMEs is that the hierarchy is often contracted, and decisionmaking is centralized at owner/manager level. The organization chart is rarely formalized. In SMEs, the owner/manager's personality, skills, responsibilities, attitudes, and behavior have a decisive influence on the organization strategy. He/she has a significant influence in supporting organizational knowledge programs and practices. 
Therefore, building relationship becomes necessary. Also, the situation that there is often less competition among the co-workers compared to their counterparts in larger businesses may facilitate the willingness to share knowledge (Hislop, 2009). A further advantage may be associated with the company size. Functions and names are attached to a person and their face.

Only $16 \%$ of surveyed companies organize the so-called open projects to which they invited outside partners (stakeholders). SMEs do not recognize the potential of creating new knowledge from outside and thus generating external innovations. Almost every fourth respondent party abolished the rigid divisions between functional departments, which are often perceived as socalled silos. This can have a devastating effect on the business.

Levy et al. (2003) state that SMEs are knowledge creators but are poor at knowledge retention. They need to be proactive in knowledge sharing arrangements to recognize that knowledge has value and the value added is derived from knowledge exchange. The division into functional departments often causes "will remain in their own section" which is reflected in the lack of cooperation between functional departments.

New skills and competencies of the employees have a vital role that plays in the survival of an organization. $17 \%$ of the respondents acknowledge that participating in training/workshops allow them to create new knowledge.

People do not like change. It takes time and effort to get people to accept and learn new ways of working in such a way that they are able to apply them with ease. Owner/ managers must understand the value of investing in $\mathrm{KM}$ and the benefits of allowing people to have resources for effective KM practices.

Employees should not be afraid of making mistakes but should be encouraged to share the lessons learned in order to curb repetitions of the same mistakes. An environment that allows this to prevail is likely to contribute positively to a culture that supports KM in organizations. Low tolerance of mistakes and the lack of policies to address conflict management deter employees from contributing to the knowledge creation process (Wee and Chua, 2013). Methods of generating new knowledge based on selected criteria to differentiate the examined companies are shown in Table 3 . 
Table 3: Generating knowledge considering differentiation criteria

\begin{tabular}{|c|c|c|c|c|c|c|c|c|c|c|c|}
\hline \multicolumn{2}{|c|}{$\begin{array}{l}\text { Differentiation } \\
\text { Criteria }\end{array}$} & 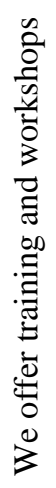 & 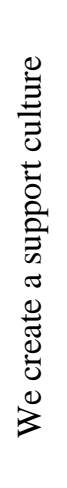 & $\begin{array}{l}0 \\
0 \\
0 \\
0 \\
0 \\
0 \\
0 \\
0 \\
\frac{0}{3} \\
0 \\
0 \\
0 \\
0 \\
0 \\
0 \\
0 \\
0 \\
0 \\
0 \\
0\end{array}$ & 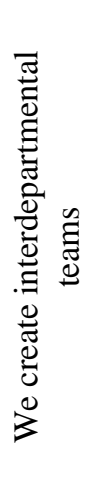 & 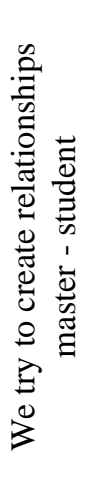 & 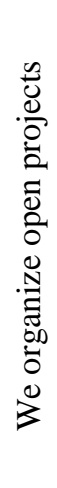 & 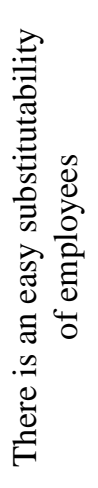 & 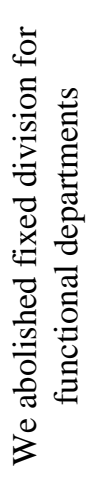 & 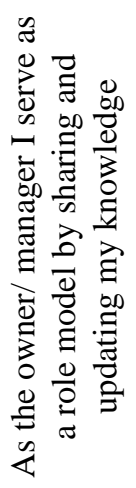 & 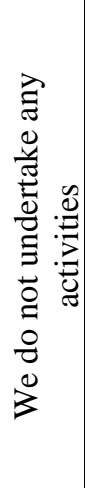 \\
\hline \multirow[b]{3}{*}{ Sector } & Production & 20 & 35 & 25 & 37 & 28 & 13 & 21 & 16 & 17 & 7 \\
\hline & Trade & 37 & 27 & 17 & 39 & 15 & 27 & 2 & 24 & 32 & 5 \\
\hline & Services & 32 & 43 & 32 & 32 & 8 & 8 & 14 & 19 & 35 & 0 \\
\hline \multirow{3}{*}{$\begin{array}{c}\text { Type of } \\
\text { ownership }\end{array}$} & Ltd & 28 & 37 & 25 & 37 & 17 & 17 & 15 & 18 & 24 & 3 \\
\hline & Joint Stock company & 38 & 24 & 19 & 29 & 29 & 14 & 10 & 24 & 24 & 14 \\
\hline & Sole proprietorship & 0 & 22 & 33 & 44 & 33 & 0 & 22 & 22 & 44 & 0 \\
\hline \multirow[b]{2}{*}{$\begin{array}{l}\text { Ownership } \\
\text { capital }\end{array}$} & $\begin{array}{c}\text { Majority of the } \\
\text { Polish capital }\end{array}$ & 30 & 35 & 27 & 37 & 21 & 14 & 14 & 18 & 25 & 3 \\
\hline & $\begin{array}{c}\text { Majority of foreign } \\
\text { capital }\end{array}$ & 6 & 33 & 6 & 33 & 6 & 28 & 17 & 28 & 28 & 17 \\
\hline \multirow{3}{*}{$\begin{array}{l}\text { Scope of } \\
\text { operation }\end{array}$} & International & 23 & 34 & 18 & 35 & 23 & 16 & 17 & 17 & 21 & 8 \\
\hline & National & 30 & 38 & 30 & 41 & 16 & 16 & 10 & 17 & 30 & 2 \\
\hline & Regional/ local & 38 & 23 & 38 & 23 & 15 & 15 & 23 & 38 & 31 & 0 \\
\hline \multirow{2}{*}{$\begin{array}{l}\text { Number of } \\
\text { employees }\end{array}$} & 10-49 persons & 34 & 38 & 31 & 36 & 17 & 19 & 14 & 14 & 26 & 1 \\
\hline & 50-249 persons & 21 & 32 & 18 & 37 & 22 & 12 & 14 & 24 & 25 & 8 \\
\hline
\end{tabular}

Source: Authors' own development based on statutory research of the Management Institute $(\mathrm{N}=153)$

By analyzing longitudinal data, the results show many interesting relationships. The highest percentage of respondents in relation to organizing training, workshops is taking place in trade activities - $37 \%$ of entities in joint stock companies, $38 \%$ in companies with the majority of Polish capital and in companies with the regional scope of operation and employing 10 to 49 employees $-34 \%$.

It is very important to create a master-student relationship, the results confirm the assumptions. $28 \%$ of those involved in the production activity confirm the creation of such ties, at least, this relation is present only in $8 \%$ of service companies. The master-student relationship seems to be very popular amongst sole proprietorship as reported by $33 \%$ of companies surveyed. This may be caused that a manager and employee have a natural good working relationship. 
The key person in the company, the so-called - agents of knowledge are present in the service sector - 33\%, in sole proprietorship and in companies with predominantly Polish capital - $27 \%$ regional and $38 \%$ of the average (from 10 to 49 people) $-31 \%$.

Teams are formed in trading companies - 39\%, with the majority of Polish capital - $37 \%$ and in companies who operate on national market $41 \%$. The existence of organizational structures such as a team dedicated to problem solving and technology incubation structures (So, 2010) can help with the creations of knowledge. Organizing open projects to which external stakeholders are invited is popular in the retail sector $27 \%$ and service sector - $8 \%$. Sole properties are not in any way interested in open projects. This may be due to the conviction of self-sufficiency and the traditional conception of knowledge (which is to be formed within the company).

The functioning of the substitutability of employees is popular among production companies $19 \%$ as it may be a result of ensuring the continuity of production. The same attitude is present amongst sole proprietorship.

Elimination of rigid division into functional departments is most pronounced among companies in the retail sector. This may be due to the specific nature of this industry, where profit is generated at the interface between the company and the customer and the excellent customer service can guarantee above-average profits and provide a competitive advantage.

Analyzing the behavior of the manager/owner of the company, it can safely be said that the company is as good as its manager/owner. Employees are always looking up to the manager/owner who enforces company's norms and behavior. The owner/manager is an indicator of the standard of work.

Moreover, the question that was asked whether there was significant relationship between the following variables (training or workshops, support culture, knowledge agents, interdepartmental teams, relationship master-student, open projects, substitutability of employees, abolished fixed divisions, role model of owner, no activities) and (sector, type of ownership, ownership capital, scope of operation, and number of employees) was answered. Analyzed variables are of qualitative character, therefore, chi-square statistic was utilized which enables to show relations between qualitative variables. The test was conducted assuming $\alpha=0.05$. The results of the analysis are presented in Table 4. 
Table 4: Chi-square statistic results

\begin{tabular}{|l|l|l|l|l|l|}
\hline & Sector & $\begin{array}{c}\text { Type of } \\
\text { ownershi } \\
\mathrm{p}\end{array}$ & \multicolumn{5}{|c|}{$\begin{array}{c}\text { Ownershi } \\
\text { p capital }\end{array}$} & $\begin{array}{c}\text { Scope of } \\
\text { operatio } \\
\mathrm{n}\end{array}$ & $\begin{array}{c}\text { Number } \\
\text { of } \\
\text { employee } \\
\mathrm{s}\end{array}$ \\
\hline & \multicolumn{5}{|c|}{$p-$ value } \\
\hline We offer training and workshops & 0.9772 & 0.7084 & 0.6117 & 0.2241 & 0.2509 \\
\hline We create a support culture & 0.7712 & 0.1702 & 0.9733 & 0.5355 & 0.1218 \\
\hline We identified knowledge agents & 0.6563 & 0.5136 & 0.1539 & 0.3867 & 0.2242 \\
\hline We create interdepartmental teams & 0.1418 & 0.4393 & 0.0648 & 0.5708 & 0.4638 \\
\hline We try to create relationships master - student & 0.1317 & 0.2706 & 0.3804 & 0.6114 & 0.9557 \\
\hline We organize open projects & 0.5293 & 0.2754 & 0.1524 & 0.1154 & 0.9952 \\
\hline There is an easy substitutability of employees & 0.8276 & 0.1836 & 0.2602 & 0.0935 & 0.2380 \\
\hline We abolished fixed division for functional departments & 0.3697 & 0.7853 & 0.1113 & 0.4442 & 0.0583 \\
\hline $\begin{array}{l}\text { As the owner/manager, I serve as a role model } \\
\text { by sharing and updating my knowledge }\end{array}$ & $\mathbf{0 . 0 0 5 8 * *}$ & 0.5136 & 0.7351 & 0.4367 & 0.1534 \\
\hline We do not undertake any activities & 0.8168 & 0.4311 & 0.8327 & 0.0735 & 0.0509 \\
\hline
\end{tabular}

Source: Source: Authors' own development based on statutory research of the Management Institute (N=153)

Based on the analysis, only one variable "As the owner/manager I serve as a role model by sharing and updating my knowledge" showed a significant correlation $(\mathrm{p}=0.0058)$ with the variable of the sector. Figure 2 shows the highest percentage occurs in trading companies (36\%) and the lowest in production companies $(14 \%)$.

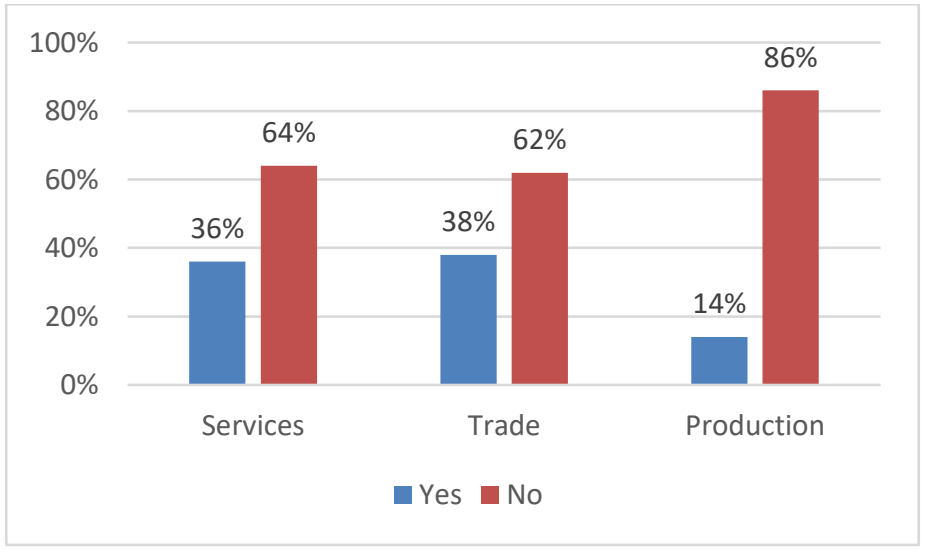

Figure 2: Influence of sector

Source: Author's own development based on statutory research of the Management Institute $(\mathrm{N}=153)$

The conviction of knowledge and its sharing is the basis of a healthy organization. It is interesting that there is only a very small number of companies that do not take any action to create new knowledge. 


\section{Conclusions, limitations, and directions for further research}

Mainstream knowledge management research historically focused on knowledge sharing processes in large organizations (Al Mehairi, 2013). Typically, these knowledge sharing processes are supported by knowledge management systems. However, knowledge processes should be regarded as a set of inter-related activities, not a simple combination of individual activities, that as a whole is linked to the organizational performance (Intezari et al., 2017). In contrast to the general focus on knowledge sharing processes in large organizations, this study focused on knowledge creation processes in SMEs and tried to identify the various organizational mechanisms and activities they employ to improve or support knowledge creation processes.

Compared to large firms, SMEs are relatively under-resourced in terms of financing, planning, training and the use of information systems. Their small size means that they tend to have flatter organizational structures and their management is more informal and ad hoc when compared to large organizations.

The results of the survey show that SME's do take knowledge management seriously and that they specifically try to support knowledge creation processes. Only a tiny minority of the surveyed organizations undertake no targeted activities to support knowledge creation.

According to Wong (2005) and Valmohammadi (2010) cooperation has been empirically proven as a factor contributing to knowledge creation. Cooperation provides opportunities for employees with different backgrounds and experiences to work together, facilitating and streamlining the process of creating new knowledge.

The establishment of interdepartmental teams and the cultivation of a support culture were the two most popular activities undertaken in support of knowledge creation processes with more than a third of the SMEs engaging in it.

Around a quarter of the SMEs focus on providing training and the setting of examples, either in the form of owner role models or in the form of knowledge agents identified as key people.

All the other activities were found in less than a fifth of the SMEs surveyed. One would expect that companies with a small size will try and source outside knowledge at every opportunity, but the results show that less than a sixth of the SMEs engage in open projects where they have the opportunity for new knowledge to be injected by outsiders.

It was also clear from the responses that SMEs make up for their relative lack of resources, by leveraging their smaller size through focusing on activities aimed at improved interaction between employees and seek to control and coordinate by cultural means. The emphasis on teamwork and training aimed at interaction and the support culture and role-models aim at instilling a knowledge culture for control and coordination. 
What is less clear from this study is whether this dual strategy is a result of their relatively small size and lack of resources, or whether successful knowledge creation depends on a combination of interaction and normative controls regardless of organization size.

What we can conclude is that, whilst managing knowledge creation processes in SMEs is a challenging task due to constraints associated with their small scale of operation, lack of resources, and relatively deficient infrastructure, SMEs turn their small size into an advantage by doing precisely what larger organizations cannot do without much effort and that is to emphasize tacit knowledge through face-to-face interaction, teamwork and establishing a culture conducive to knowledge creation through the cult of an owner or key persons as role models.

Lastly, we can speculate whether knowledge creation is perhaps less dependent on information systems support than other knowledge processes like sharing knowledge. Perhaps SMEs by virtue of their relatively smaller size need explicit knowledge sharing less than bigger firms and therefore can focus on interactive processes facilitating tacit knowledge shared during the interaction.

This study can be further expanded to include a larger sample for better generalizability of results. Cross country comparison might provide interesting insights. Future in-depth research can be carried out over the issues raised in this paper.

\section{References}

Al Mehairi, H. (2013). Cultural influences on knowledge sharing behaviours through open systems closed system cultures: the impact of organisational culture on knowledge sharing. Proceedings of the International Conference on Intellectual Capital, Washington, DC, 2425 October.

Amelingmeyer, J. and Amelingmeyer, G. (2005). Wissensmanagement beim Fu “hrungswechsel in $K M U$, in Meyer, J.-A. (Ed.), Wissens- und Informationsmanagement in kleinen und mittleren Unternehmen, Josef Eul Verlag, Lohmar, Cologne, pp. 479-488.

Andreeva, T. \& Kianto, A. (2011). Knowledge processes, knowledge-intensity and innovation: a moderated mediation analysis. Journal of Knowledge Management, 15 (6), pp. 1016-1034.

Autio, E., Sapienza, H.J. \& Almeida, J. (2000). Effects of age at entry, knowledge intensity and imitability on international growth. Academy of Management Journal, 43 (2), pp. 909-924.

Becerra-Fernandez, I., Gonzalez, A. \& Sabherwal, R. (2004). Knowledge Management: Challenge, Solutions, and Technologies, Prentice-Hall, Upper Saddle River, NJ.

Chang, S.C. \& Lee, M.S. (2008). The linkage between knowledge accumulation capability and organizational innovation. Journal of Knowledge Management, 12 (1), pp. 3-20.

Daft, R.F. (2007). Understanding the Theory and Design of Organizations, Thomson SouthWestern, Mason, $\mathrm{OH}$.

Desouza, K. C., \& Awazu, Y. (2006). Knowledge management at SMEs: five peculiarities. Journal of knowledge management, 10(1), 32-43. 
Desouza, K.C. \& Awazu, Y. (2006). Knowledge management at SMEs: five peculiarities. Journal of Knowledge Management, 10 (1), pp. 32-43.

Durst S. \& Edvardsson I. R., (2012). Knowledge management in SMEs: a literature review. Journal of Knowledge Management, 16 (6) pp. 879 - 903.

Egbu, C.O., Hari, S. \& Renukappa, S.H. (2005). Knowledge management for sustainable competitiveness in small and medium surveying practices. Structural Survey, 23 (1), pp. 722.

Hislop, D. (2009). Knowledge Management in Organizations, 2nd ed., Oxford University Press, Oxford.

Intezari I., Taskin N., \& Paullen D. J. (2017), Looking beyong knowledge sharing: an integrative approach to management culture. Knowledge Management, 21, (2), pp. 492-515.

Jarillo, J.C. (1989). Entrepreneurship and growth: the strategic use of external resources. Journal of Business Venturing, 4 (2), pp. 133-147.

Jennex, M.E. \& Zynger, S. (2007), Security as a contributor to knowledge management success. Information Systems Frontiers, (9), pp. 493-504.

Lee Ch. S., \& Kelkar S. R., (2013). ICT and knowledge management: perspectives from the SECI model. The Electronic Library, 31 (2), pp. 226-243

Levy, M., Loebbecke, C. \& Powell, P. (2003). SMEs, co-opetition and knowledge sharing: the role of information system. European Journal of Information System, 12, pp. 3-17.

Martin, C., Martin, L., \& Mabbett, A. (2002). SME ownership succession: Business support and policy implications. Sheffield: SBS Research Directorate.

Nonaka, I. (1994). A dynamic theory of organizational knowledge creation. Organization Science, 5 (1), pp. 14-37.

Nonaka, I. and Takeuchi, H. (1995). The Knowledge-Creating Company, Oxford University Press, Oxford.

Nonaka, I. and Takeuchi, H. (1997). The Knowledge Creating Company, Oxford University Press, New York, NY.

Nor Shahriza A. K., Jalaldeen M. R., \& Norshidah M., (2012). Measuring employee readiness for knowledge management using intention to be involved with KM SECI processes. Business Process Management Journal, 18 (5), pp. 777-791.

Polish Agency of Entrepreneurship Development (2016). State of small and medium enterprises in Poland, Warsaw. Retrieved December 04, 2016 from https://badania.parp.gov.pl/raporto-stanie-sektora-msp/stan-sektora-msp-w-polsce

Prahalad, C.K. \& Hamel, G. (1990). The core competence of the corporation. Harvard Business Review, 68 (3), pp.79-91.

Randeree, E. (2006). Knowledge management: securing the future. Journal of Knowledge Management, 10 (4), pp.145-156. 
Schulz, M. (2001). The uncertain relevance of newness: Organizational learning and knowledge flows. Academy of management journal, 44(4), 661-681.

Serenko, A. (2013). Meta-analysis of scientometric research of knowledge management: discovering the identity of the discipline. Journal of Knowledge Management, 17 (5), pp. 773-812.

Shih, K. H., Chang, C. J., \& Lin, B. (2010). Assessing knowledge creation and intellectual capital in banking industry. Journal of Intellectual Capital, 11(1), 74-89.

Smith, K., Collins, C. \& Clark, K. (2005), Existing knowledge, knowledge creation capabilityan $\mathrm{d}$ the rate of new product introduction in high-technology firms. Academy of Management Journal, 48 (2), pp. 346-357.

So, C.K. (2010), How the Introduction of Intellectual Capital Management Inspired a Business Model in Hong Kong, China, The Hong Kong Institute of High Performance, Hong Kong.

Teece, D. (2005). Technology and technology transfer: mansfieldian inspirations and subsequent developments. Journal of Technology Transfer, 30 (1-2), pp.17-33.

Thorpe, R., Holt, R., Macpherson, A., \& Pittaway, L. (2005). Using knowledge within small and medium-sized firms: A systematic review of the evidence. International Journal of Management Reviews, 7(4), 257-281.

Valmohammadi, C., Identification and prioritization of critical success factors of knowledge management in Iranian SMEs: an experts' view. African Journal of Business Management, 4, (6), 2010, s. 915-924.

Varun Grover, T. \& Davenport. , H. (2001). General perspectives on knowledge management: Fostering a research agenda. Journal of management information systems, 18(1), 5-21.

Wee J. C.N., Chua A. Y.K, (2013), The peculiarities of knowledge management processes in SMEs: the case of Singapore. Journal of Knowledge Management, 17 (6), pp. 958 - 972.

Wilhelm S., Durst. S. (2012), Knowledge management and succession planning in SMEs. Journal of Knowledge Management, 16 (4), pp. 637 - 649.

Wong, K.Y., Critical success factors for implementing knowledge management in small and medium enterprises. Industrial Management and Data Systems, 105 (3), 2005, pp. 261279.

\section{Author's Biography}

Celina Solek-Borowska, Ph.D. is Assistant Professor at the Warsaw School of Economics, Warsaw, Poland. She also serves as a business consultant. Her research interests focus on knowledge creation and sharing practices amongst businesses and universities, competition in the higher education sector, and teamwork. She has taught in the Erasmus program for the University of Gran Canaria, the University of Hertfordshire, and the University of Alicante. 